\title{
PERANCANGAN MODEL PEMBINAAN KEWIRAUSAHAAN TERPADU BAGI MASYARAKAT PENERIMA PROGRAM BANTUAN PEMERINTAH DI KECAMATAN SAMARINDA ILIR
}

\author{
Oleh: \\ Suyanto* \\ ( ${ }^{\star}$ Dosen Fakultas Ekonomi Universitas Widya Gama Mahakam Samarinda)
}

\section{RINGKASAN}

Pengangguran dan bertambahnya angka kemiskinan, merupakan pekerjaan rumah yang harus segera diatasi oleh pemerintah dan masyarakat yang mempunyai kepedulian terhadap permasalahan tersebut. Lembaga pendidikan melalui para dosen dan mahasiswa berupaya membantu pemerintah khususnya dalam mengurangi jumlah pengangguran dan pengentasan kemiskinan dengan melakukan penelitian terhadap keluarga pra sejahtera/miskin yang berpotensi untuk dapat dilakukan pembinaan dengan pelatihan-pelatihan ketrampilan sesuai dengan bakat masing-masing sebagai bekal untuk berwirausaha.

Dengan adanya penelitian dan pembinaan yang dilakukan diharapkan keluarga pra sejahtera mampu mengorganisir sumber daya yang dimiliki untuk mendapatkan hasil yang efektif dan efisien, sehingga dapat mensejahterakan kehidupan baik untuk sendiri maupun keluarganya. Disamping itu ,mereka juga diharapkan dapat memahami tentang pasar dan memahami upaya - upaya yang dilakukan untuk menembus pasar. Model pembinaan kewirausahaan disesuaikan dengan potensi yang dimiliki oleh responden.

Kata Kunci: Kemiskinan, kewirausahaan

\section{PENDAHULUAN.}

\section{Latar Belakang}

Penduduk yang bermukim di wilayah Samarinda llir berdasarkan data dari Kantor Kecamatan Samarinda Ilir adalah 56.381 jiwa, dengan komposisi penduduk laki-laki 20.630 jiwa dan perempuan 35.751 jiwa. Angka tersebut diyakini akan terus bertambah dikarenakan pertambahan jumlah penduduk yang tidak bisa dihindari. Dengan bertambahnya penduduk, berakibat pula bertambahnya jumlah dan komposisi tenaga kerja yang perlu mendapat perhatian pemerintah. Ketidak seimbangan antara jumlah angkatan kerja dan lowongan kerja, dapat menimbulkan masalah-masalah sosial.

Kecamatan Samarinda llir memiliki 5 kelurahan yaitu kelurahan Sidomulyo, Pelita, Sungai Dama, Selili dan Sidodamai. Dikecamatan tersebut terdapat 1.482 Kepala keluarga yang masuk dalam kategori keluarga pra 
sejahtera dan 1.756 Kepala Keluarga masuk dalam kategori Keluarga Miskin. Data mengenai penerima program pemerintah diantaranya program Raskin sebanyak 1.756 Kepala keluarga ( RASKIN dan BLT), untuk itu perlu dilakukan pemberdayaan masyarakat miskin melalui Pengembangan Kewirausahaan Terpadu, yaitu dengan melakukan pembinaan ketrampilan individu, memberi motivasi serta mengefektifkan penggunaan faktor-faktor produksi (tanah atau sumber daya alam, tenaga kerja atau sumber daya manusia , modal, dan manajerial skill) disamping itu faktor lain adalah market. Mengacu pada permasalah tersebut maka judul yang penulis ajukan adalah ; Perancangan Model Pembinaan Kewirausahaan Terpadu Bagi Masyarakat Penerima Program Bantuan Pemerintah di Kecamatan Samarinda llir

\section{Perumusan Masalah.}

1. Hal apa saja yang dihadapi oleh keluarga miskin berkaitan dengan keadaan ekonominya, pekerjaan yang dilakukannya, minat dan bakat yang dimiliki sehingga memungkinkan untuk diberdayakan melalui pengembangan wirausaha sebagai upaya untuk meningkatkan kesejahteraan mereka atau sebagai upaya untuk pengentasan kemiskinan.

2. Strategi apa yang harus dilakukan untuk memberdayakan keluarga miskin di kelurahan Samarinda llir.

\section{Tujuan Penelitian}

1. Untuk mendapatkan informasi tentang program-program bantuan pemerintah selama ini yang bertujuan mengentaskan kemiskinan, apakah sudah tepat sasaran atau belum.

2. Mengidentifikasi keluarga pra sejahtera yang berminat berwiraswasta dengan Pekerjaan yang selama ini ditekuninya

3. Megidentifikasi ketrampilan yang diminati oleh keluarga pra sejahtera guna dilakukan pembinan lebih lanjut.

4. Merancang model pembinaan wirausaha yang cocok bagi keluarga pra sejahtera

5. Mengetahui pemahaman mereka yang menyangkut tentang pengelolaan faktor-faktor produksi.

6. Adanya model pembinaan dan pemberdayaan masyarakat pra sejahtera yang cocok untuk pengembangan berwirausaha guna meningkatkan kesejahteraan mereka, melalui pendekatan konsep secara persuasif.

\section{TINJAUAN PUSTAKA.}

\section{Studi Pendahuluan}

Kemiskinan adalah keadaan dimana terjadi kekurangan hal-hal yang biasa untuk dipunyai seperti makanan, pakaian, tempat berlindung dan air minum, hal-hal ini berhubungan erat dengan kualitas hidup . Kemiskinan kadang juga berarti tidak adanya akses terhadap pendidikan dan pekerjaan yang mampu mengatasi masalah kemiskinan dan mendapatkan kehormatan yang layak sebagai warga negara. Kemiskinan merupakan masalah global. Sebagian orang memahami istilah ini secara subyektif dan komparatif, sementara yang lainnya melihatnya dari segi moral dan evaluatif, dan yang lainnya lagi memahaminya 
dari sudut ilmiah yang telah mapan. Istilah "negara berkembang" biasanya digunakan untuk merujuk kepada negara-negara yang "miskin".

Indonesia termasuk Negara yang sedang berkembang, kemiskinan masih menjadi gambaran kehidupan sebagian besar rakyat Indonesia baik di pedesaan maupun diperkotaan. Untuk mengetahui siapa yang termasuk keluarga miskin atau keluarga miskin, perlu diukur dengan beberapa kriteria yang telah ditentukan oleh pemerintah (register pendataan keluarga tahun 2008) adalah sebagai berikut :

1. Keluarga yang hanya mampu makan kurang dari 2 kali sehari.

2. Keluarga yang tidak mempunyai perbedaan pakaian antara di rumah, bekerja/ sekolah maupun bepergian.

3. Rumah yang ditempati keluarga mempunyai atap, lantai dan dinding yang kurang layak.

4. Bila ada keluarga yang sakit tidak dibawa ke sarana kesehatan karena tidak mempunyai biaya untuk pengobatan.

5. Bila pasangan usia subur ingin ber KB tidak pergi ke sarana pelayanan kontrasepsi karena alasan tidak mempunyai biaya.

\section{Program-program Pemerintah yang telah dijalankan untuk pengentasan kemiskinan}

Program-program pemerintah yang telah dijalankan baik dengan menggunakan APBN maupun APBD adalah sebagai berikut ; (sumber : Kecamatan Samarinda llir Kota Samarinda )

1. Raskin.

Merupakan bantuan pemerintah berupa beras dengan tujuan meringankan beban masyarakat pra sejahtera dalam memenuhi kebutuhannya untuk makan. Setiap kepala keluarga diberi beras $15 \mathrm{~kg}$ per bulan. Data diperoleh melalui RT dengan berpedoman pada kreteria keluarga pra sejahtera. Raskin ini dianggarkan melalui APBN.

2. Jamkesmas.

Adalah jaminan kesehatan masyarakat bagi keluarga pra sejahtera atau rumah tangga miskin. Jamkesmas ini dianggarkan melalui APBN. Karena jamkesmas ini merupakan program yang dibuka tidak setiap saat maka ada beberapa masyarakat yang tidak menerima jamkesmas dengan berbagai alasan. Untuk membantu masyarakat yang tidak terdata sebagai penerima jamkesmas maka walikota Samarinda menganggarkan dana khusus bidang kesehatan melalui APBD, dengan tujuan membantu mereka yang membutuhkan pengobatan. Dalam melakukan pengobatan melalui jamkesmas yang dianggarkan oleh APBD ini, tentunya ada beberapa syarat yang harus dipenuhinya yaitu dengan membuat surat keterangan tidak mampu dari RT, disyahkan RW dan kelurahan.

3. BLT.

Merupakan bantuan langsung tunai dari pemerintah berupa uang kepada masyarakat rumah tangga miskin yang bertujuan untuk meringankan beban kehidupannya. BLT ini dianggarkan melalui APBN, diberikan kepada masyarakat setiap triwulan sebesar Rp.300.000,-

4. PNPM (Program Nasional Pemberdayaan Masyarakat).

Program ini dianggarkan dari Kesra dan Depatemen PU. Dikelola oleh BKM (Badan Keswadayaan Masyarakat) yang terdiri terdiri dari perwakilan masingmasing RT . program ini bertujuan untuk membantu masyarakat pra sejahtera 
yang memerlukan bantuan dana baik untuk modal awal mapun untuk bantuan modal tambahan secara bergulir. Peminjaman ini dikenakan jasa 1,5\% per bulan untuk biaya administrasi dan tambahan modal. Untuk mendapatkan dana PNPM, harus mengajukan proposal atas rekomendasi dari RT. Dalam pengajuan dana harus secara Kelompok minimal 3 orang dan maksimal 10 orang.

Dengan program-program tersebut diatas, apakah masyarakat yang termasuk keluarga pra sejahtera dan sejahtera 1 sudah pernah mendapatkan pinjaman atau belum. Melalui penelitian ini akan diketahui program-program pemerintah baik Pusat maupun Daerah sudah tepat sasaran atau belum.

\section{Model pembinaan wirausaha yang cocok bagi rumah tangga miskin.}

Mengingat keluarga pra sejahtera pada umumnya berpengetahuan rendah, maka perlu disederhanakan dalam melakukan pembinaan terhadap mereka. Adapun pembinaan yang ditawarkan adalah :

1. Diberi pembekalan tentang jiwa wirausaha

Jiwa yang bagaimana yang harus dimiliki oleh seorang wirausaha?. Jiwa yang perlu ditanamkan tentunya adalah mempunyai sikap mandiri, bekerja keras, siap dengan tantangan, mampu memanfaatkan momen dan berjiwa kompetitif.

2. Diberi bimbingan bagaimana membuka usaha mandiri dengan membuat Rencana Perusahaan. Mas'ud Machfoedz (2005;57)

Tabel 1

Rencana Perusahaan

\section{Perencanaan Perusahaan.}

Meliputi tentang sifat perusahaan, pasar sasaran, kelebihan-kelebihan perusahaan terhadap pesaing, sumber dana serta kualifikasi pemiliknya.

\section{Pembiayaan modal.}

Modal bisa diperoleh dari ; milik sendiri, pinjam dari keluarga/teman, bantuan dan Bank.modal harus dirinci secara jelas.

\section{Pengenalan Pasar.}

Dalam menganalisa pasar yang dibicarakan adalah ukuran pasar,sasaran, kebutuhan produk/jasa dan sifat persaingan.

\section{Pengelolaan karyawan.}

Meliputi deskripsi pekerjaan, bagan organisasi, manajer mempunyai keahlian yang diperlukan untuk mengawali dan mengoperasikan perusahaan

Pencatatan akuntansi.

Menghasilkan laporan yang menerangkan kondisi keuangan perusahaan 
Wirausaha.

Lebih lanjut Mas'ud Machfoedz (2004; 12), profil seorang wirausaha digambarkan sbb :

Tabel 2.

Profil Wirausaha

\begin{tabular}{|l|l|}
\hline \multicolumn{1}{|c|}{ Profil Wirausaha } & \multicolumn{1}{|c|}{ Sifat kewirausahaan } \\
\hline Mengejar prestasi & $\begin{array}{l}\text { Lebih melilih bekerja dengan pakar untuk mencapai } \\
\text { tujuan prestasi. }\end{array}$ \\
\hline Berani mengambil resiko & $\begin{array}{l}\text { Tidak takut mengambil resiko dengan sedapat } \\
\text { mungkin menghindari resiko besar. }\end{array}$ \\
\hline $\begin{array}{l}\text { Mampu memecahkan } \\
\text { permasalahan }\end{array}$ & $\begin{array}{l}\text { Mampu mengidentifikasi dan memecahkan } \\
\text { permasalahan yang dapat menjadi kendala bagi } \\
\text { kemampuan mereka untuk mencapai tujuan. }\end{array}$ \\
\hline Rendah hati & $\begin{array}{l}\text { Lebih mengutamakan misi bisnis daripada } \\
\text { mengejar status }\end{array}$ \\
\hline Bersemangat & $\begin{array}{l}\text { Bersedia bekerja keras untuk membangun usaha } \\
\text { Mengandalkan kepercayaan diri untuk mencapai } \\
\text { keberhasilan }\end{array}$ \\
\hline Percaya diri & $\begin{array}{l}\text { Menghindari hubungan emosional yang dapat } \\
\text { mengganggu keberhasilan bisnis. }\end{array}$ \\
\hline Menghindari sifat cengengang struktur organisasi sebagai kendala \\
\hline Kepuasan diri & $\begin{array}{l}\text { Memandang stram memenuhi keinginan. } \\
\text { dalam }\end{array}$ \\
\hline
\end{tabular}

Untuk mengenal lebih lanjut tentang perusahaan, khususnya erusahaan kecil, dibawah ini diuraikan tentang kelemahan dan kelebihan perusahaan kecil, Mas'ud Machfoedz (2004; 58-59)

Tabel 3.

Keunggulan/Kelemahan Perusahaan Kecil

\begin{tabular}{|l|l|}
\hline KEUNGGULAN/KELEBIHAN & KELEMAHAN/KEKURANGAN \\
\hline $\begin{array}{l}\text { Fleksibel } \\
\text { - Pada umumnya dikelola } \\
\text { oleh pemilik, sehingga }\end{array}$ & $\begin{array}{l}\text { Keterbatasan kecakapan manajerial. } \\
\text { Cepat bereaksi terhadap }\end{array}$ \\
$\begin{array}{l}\text { perubahan pasar. } \\
\text { baik sehingga sulit menghadapi } \\
\text { perubahan yang cepat. }\end{array}$ \\
$\begin{array}{l}\text { Dapat mengembangkan ide } \\
\text { produk dan kesempatan } \\
\text { pasar tanpa tanpa melalui } \\
\text { proses persetujuan yang } \\
\text { panjang. }\end{array}$ \\
$\begin{array}{l}\text { Banyak yang tidak memiliki latar } \\
\text { belakang bisnis dan variasi } \\
\text { ketrampilan terbatas sehingga } \\
\text { sulit menghadapi persaingan. }\end{array}$ \\
\hline
\end{tabular}




\begin{tabular}{|c|c|}
\hline $\begin{array}{l}\text { Lebih } \text { efisien } \\
\text { pengoperasian. } \\
\text { - Lebih sederhana, baik } \\
\text { tentang jumlah pekerja } \\
\text { maupun biaya yang } \\
\text { dikeluarkannya. } \\
\text { - Jika perlu bantuan, } \\
\text { memanfaatkan pihak luar } \\
\text { sesuai keperluan. }\end{array}$ & $\begin{array}{l}\text { Kesulitan mengembangkan dana. } \\
\text { - Sulit mendapatkan dana yang } \\
\text { cukup untuk pembiayaan } \\
\text { perusahaan, karena harus } \\
\text { bersaing dengan perusahaan } \\
\text { besar. } \\
\text { - Lebih memiliki semangat } \\
\text { daripada kecakapan manajerial } \\
\text { dan modal }\end{array}$ \\
\hline $\begin{array}{l}\text { Pelayanan yang akrab. } \\
\text { - Dapat memberikan } \\
\text { sentuhan pribadi kepada } \\
\text { konsumen. } \\
\text { - Mendapat umpan balik } \\
\text { secara langsung untuk } \\
\text { mengetahui kebutuhan } \\
\text { pasar }\end{array}$ & $\begin{array}{l}\text { Alasan keuangan sebagai sebab } \\
\text { wirausaha tidak dapat bertahan lama: } \\
\text { - Mulai usaha dengan modal yang } \\
\text { terlalu kecil. } \\
\text { - Mulai usaha dengan modal yang } \\
\text { besar tetapi kurang cermat } \\
\text { dalam penggunaannya, } \\
\text { - Meminjam uang tanpa } \\
\text { perencanaan pembayaran } \\
\text { kembali. } \\
\text { Mencoba terlalu banyak untuk } \\
\text { melakukan sesuatu tanpa modal } \\
\text { yang cukup. }\end{array}$ \\
\hline
\end{tabular}

Dalam melakukan usaha, wirausahawan tidak selamanya mengalami keberuntungan atau kegagalan. Dibawah ini diuraikan tentang penyebab kegagalan dan bagaimana solusinya dalam menangani perusahaan kecil. Mas'ud Machfoedz (2004; 61),

Tabel 4.

Penyebab Utama kegagalan Perusahaan Kecil dan Solusinya

\begin{tabular}{|l|l|l|l|}
\hline \multicolumn{1}{|c|}{$\begin{array}{c}\text { Sebab } \\
\text { Kegagalan }\end{array}$} & Alasan Kegagalan & $\begin{array}{l}\text { Faktor yang Perlu } \\
\text { Diperhatikan }\end{array}$ & \multicolumn{1}{|c|}{ Solusi } \\
\hline $\begin{array}{l}\text { Pasar terlalu } \\
\text { padat, banyak } \\
\text { perusahaan } \\
\text { sejenis. }\end{array}$ & $\begin{array}{l}\text { Terlalu banyak } \\
\text { pesaing yang } \\
\text { menawarkan produk } \\
\text { yang sama }\end{array}$ & $\begin{array}{l}\text { Konsumen hanya } \\
\text { melihat-lihat tanpa } \\
\text { membeli }\end{array}$ & $\begin{array}{l}\text { lklan yang } \\
\text { unik dan } \\
\text { berikan } \\
\text { potongan } \\
\text { harga. }\end{array}$ \\
\hline $\begin{array}{l}\text { Tidak ada } \\
\text { pembeli }\end{array}$ & $\begin{array}{l}\text { Lokasi kurang tepat, } \\
\text { harga tinggi, atau } \\
\text { kualitas rendah. }\end{array}$ & $\begin{array}{l}\text { Laporan } \\
\text { pendapatan } \\
\text { menunjukkan } \\
\text { penurunan laba } \\
\text { atau rugi }\end{array}$ & $\begin{array}{l}\text { Mengubah } \\
\text { perhatian } \\
\text { khusus } \\
\text { konsumen, } \\
\text { dan suvey } \\
\text { konsumen }\end{array}$ \\
\hline $\begin{array}{l}\text { Sulit melakukan } \\
\text { perubahan }\end{array}$ & $\begin{array}{l}\text { Pemilik cepat } \\
\text { merasa puas }\end{array}$ & $\begin{array}{l}\text { Lamban dan } \\
\text { penurunan } \\
\text { penjualan }\end{array}$ & $\begin{array}{l}\text { Menerapkan } \\
\text { program baru }\end{array}$ \\
\hline
\end{tabular}




\begin{tabular}{|l|l|l|l|}
\hline $\begin{array}{l}\text { Kurang } \\
\text { pengetahuan }\end{array}$ & $\begin{array}{l}\text { Prestasi } \\
\text { manajemen yang } \\
\text { rendah }\end{array}$ & $\begin{array}{l}\text { Kesalahan yang } \\
\text { terus menerus } \\
\text { terjadi pada bidang } \\
\text { yang kurang } \\
\text { diketahui }\end{array}$ & $\begin{array}{l}\text { Menyelenggar } \\
\text { akan program } \\
\text { pelatihan }\end{array}$ \\
\hline $\begin{array}{l}\text { Kekurangan } \\
\text { modal }\end{array}$ & $\begin{array}{l}\text { Perencanaan } \\
\text { keuangan yang } \\
\text { buruk }\end{array}$ & $\begin{array}{l}\text { Selalu kekurangan } \\
\text { uang }\end{array}$ & $\begin{array}{l}\text { Mengurangi } \\
\text { pengeluaran } \\
\text { dan } \\
\text { memantau } \\
\text { aliran kas }\end{array}$ \\
\hline $\begin{array}{l}\text { Tingkat bunga } \\
\text { yang tinggi }\end{array}$ & $\begin{array}{l}\text { Perekonomian yang } \\
\text { buruk }\end{array}$ & $\begin{array}{l}\text { Laporan berita } \\
\text { keuangan }\end{array}$ & $\begin{array}{l}\text { Mengurangi } \\
\text { pinjaman dan } \\
\text { mengetatkan } \\
\text { kebijakan } \\
\text { kredit }\end{array}$ \\
\hline $\begin{array}{l}\text { Tidak memiliki } \\
\text { rencana } \\
\text { perusahaan }\end{array}$ & $\begin{array}{l}\text { Manajemen yang } \\
\text { buruk }\end{array}$ & $\begin{array}{l}\text { Selalu mengalami } \\
\text { kejutan bisnis }\end{array}$ & $\begin{array}{l}\text { Mengembang } \\
\text { kan dan } \\
\text { menerapkan } \\
\text { rencana } \\
\text { perusahaan. }\end{array}$ \\
\hline
\end{tabular}

Berikut ini bermacam-macam bentuk usaha yang perlu diketahui oleh calon wirausaha :

1) Usaha Mandiri.

Paling banyak dikenal karena mudah dilakukan sehubungan dengan prosedurnya yang sederhana sehingga dapat didirikan, dimiliki, dioperasikan dan dibiayai secara perorangan dan semua keuntungan usaha menjadi milik sendiri. Misalnya toko/warung kelontong, toko obat, toko pengecer, toko roti dan sebagainya. Namun demikian sebelum memulai usaha, perlu dilakukan pemilihan bidang usaha yang akan ditekuni. Pemilihan bidang usaha harus disesuaikan dengan :

- Minat atau bakat. Minat atau bakat sudah ada dan dapat timbul dari dalam diri sesorang. Artinya, ketertarikan pada suatu bidang sudah tertanam dalam dirinya. Minat juga bisa tumbuh setelah dipelajari dari berbagai cara. Namun seseorang yang mempunyai minat dari dalam atau bakat dari keturunan akan lebih mudah dan lebih cepat beradaptasi dalam mengembangkan usahanya.

- Modal. Modal dalam arti luas berarti uang. Uang dapat diperoleh dari berbagai sumber, bisa dari uang sendiri, uang keluarga/kerabat, pinjaman dari teman dan sebagainya. Dalam arti sempit modal bisa berari keahlian. Jadi jika kita mempunyai keahlian bisa bergabung dengan teman/saudara yang mempunyai uang untuk mendirikan suatu usaha.

- Waktu. Untuk mendapatkan suatu hasil setiap usaha mempunyai waktu yang berbeda. Ada yang mendapatkan dalam jangka pendek (kurang dari satu tahun, misalnya ; usaha dagang, agribisnis, usaha jasa, peternakan ikan atau ayam), ada yang dalam jangka menengah (misalnya ; tanam jeruk, coklat, peternakan kambing, selanjutnya dalam jangka panjang misalnya ; pertanian karet atau kelapa sawit. 
- Laba. Maksudnya target laba yang diinginkan, kemudian jangka waktu untuk memperoleh laba (sesaat atau terus menerus). Dua hal tersebut bisa dijadikan pertimbangan untuk pendirian suatu usaha.

- Pengalaman. Pengalaman ini bisa berasal dari pengalaman pribadi maupun orang lain, karena dapat dijadikan pedoman dalam melakujkan usaha.

2) Bidang usaha yang sesuai dengan bakat dan minat, terutama untuk usaha kecil dan menengah antara lain : sektor kecantikan(membuka salon dan spa)), sektor ketrampilan (service motor atau elektronik), sektor konsultan ( konsultan hukum, manajemen dan sebagainya), sektor industri (pabrik tahu tempe), sektor tambang (penambangan pasir, emas), sektor kelautan (usaha penangkapan ikan), sektor perikanan (membuka usaha tambak), sektor perdagangan (membuka kios), sektor pendidikan (membuka pelatihan-pelatihan, sekolah-sekolah), sektor percetakan (membuka usaha foto copy, sablon), sektor seni (membuka kursus/melatih tari, melukis, mengukir), sektor kesehatan (membuka apotik, praktek dokter bersama, klinik-klinik kesehatan), sektor pariwisata (membuka biro perjalanan, karoke, penginapan).

\title{
METODEDOLOGI PENELITIAN
}

\section{Metode Penelitian}

\begin{abstract}
Metode yang digunakan dalam penelitian ini adalah dengan menggunakan metode deskriptif yaitu metode yang bertujuan untuk menggambarkan sifat sesuatu yang tengah berlangsung pada saat riset dilakukan dan memeriksa sebab-sebab dari suatu gejala tertentu. (Travers, 1978 dalam Husein Umar 1999 ;22). Kemudian riset dilakukan dengan survey yang bertujuan untuk mengukur gejala-gejala yang ada tanpa menyelidiki kenapa gejala-gejala tersebut ada. sehingga tidak perlu memperhitungkan hubungan antara variable-variabel karena hanya menggunakan data yang ada untuk pemecahan masalah daripada menguji hipotesis. (Consuelo 1988, dalam Husein Umar 1999;23.).
\end{abstract}

\section{Studi Literatur}

Studi Literatur digunakan untuk mendapatkan teori dan konsep, model maupun komponen yang relevan dengan masalah yang diteliti, termasuk kegiatan/program bantuan kepada keluarga miskin yang telah dilaksanakan oleh pemerintah selama tiga tahun kebelakang. Teori, konsep, model yang dipelajari antara lain tentang kriteria keluarga miskin, kewirausahaan, manajemen perusahaan, bentuk-bentuk badan usaha, manajemen operasi, motivasi, prilaku manusia dan praktek-praktek ketrampilan yang selama ini menjadi program baik oleh Dinas Sosial, Dinas Tenaga Kerja maupun Dinas Perindustrian. Berdasarkan teori, konsep dan studi pendahualuan yang telah diakukan, dapat dijadikan acuan untuk menentukan variabel penelitian. 


\section{Identifikasi Variabel Penelitian.}

Berdasarkan teori dan konsep yang relevan dengan masalah yang diteliti dan dari studi pendahuluan yang telah dilakukan, maka dapat diidentifikasi variabel yang dperlukan dalam penelitian ini. Identifikasi variabel dimaksudkan adalah untuk memunculkan indikator-indikator yang terkait dengan permasalahan yang diteliti yang selanjutnya digunakan sebagai acuan untuk penyusunan kuisioner. Adapun variable penelitiannya adalah sebagai berikut : Perancangan Model Pembinaan Kewirausahaan dan Pengentasan Kemiskinan

\section{Identifikasi Data yang diperlukan.}

Tahap ini dilakukan untuk menentukan data yang diperlukan dalam penelitian ini. Sesuai dengan tujuan penelitian dan alur pikir yang telah disajikan maka data-data yang diperlukan adalah tentang keadaan sosial ekonomi keluarga miskin, pekerjaan keluarga miskin yang selama ini dilakukannya, bakat dan minat yang dimiliki oleh mereka. Dengan didapatkannya data tersebut, maka dapat digunakan sebagi acuan untuk membuat model pembinaan kewirausahaan yang cocok dengan kemampuan dan karakter mereka.

\section{Prosedur Pengumpulan data.}

Cara yang dilakukan dalam pengumpulan data, antara lain dengan pengamatan langsung (observasi) ke lapangan, wawancara dan penyebaran kuisioner (untuk data primer) dan data sekunder dari instansi dan literatur yang terkait. Untuk mengidentifikasi keadaan sosial ekonomi keluarga miskin, pekerjaan keluarga miskin yang selama ini dilakukannya, bakat dan minat yang dimiliki oleh mereka dilakukan dengan observasi, wawancara dan penyebaran kuesioner yang diisi langsung oleh responden agar akurat. Sedangkan untuk pengembangan model pembinaan, digunakan teknik wawancara dan data sekunder.

\section{Identifikasi Sampel Penelitian.}

Penelitian dilakukan dengan mengambil sampel dari beberapa kelurahan di kecamatan Samarinda llir yang termasuk keluarga miskin secara acak sebanyak 94 orang, dengan pertimbangan dalam pembuatan model pembinaan kewirausahaan yang sesuai harus mengacu pada kondisi mereka.

\section{Penyusunan kuesioner.}

Dalam menyusun kuesioner, dibagai dalam dua kategori, kategori pertama mencakup profil \& identitas responden. Tujuannya untuk mengetahui lebih dekat tentang keadaan sosial ekonominya , perkerjaan yang ditekuni, minat dan bakat yang dimiliki oleh keluarga miskin sebagai sarana untuk penyusunan pembinaan wirausaha. Kategori kedua mencakup aplikasi pembinaan wirausaha yang cocok bagi keluarga miskin. Bentuk pertanyaan yang diajukan adalah pertanyaan tertutup dan terbuka.

Pertanyaan tertutup disusun secara sederhana dan disediakan pilihan jawaban untuk dipilih oleh responden. Sedangkan pertanyaan terbuka digunakan untuk 
menggali keadaan nyata yang dihadapi oleh responen dengan menulis dilembar yang telah disediakan. Pada awal setiap kelompok pertanyaan terdapat penjelasan untuk membantu responden dalam memahami maksud pertanyaan.

\section{Penyebaran kuesioner}

Tindakan selanjutnya adalah penyebaran kuesioner. Kuesioner ini disebarkan kepada masyarakat miskin yang berada di wilayah kecamatan Samarinda llir yang berumur diatas 17 tahun yang sudah siap untuk bekerja.

\section{Kerangka Konseptual}

Untuk mendapatkan data yang maksimal langkah yang ditempuh adalah ; mengidentifikasi social ekonomi keluarga miskin, Idetifikasi pekerjaan, identifikasi bakat dan minat. Dari data yang terkumpul kemudian dilakukan pembinaan dengan melakukan pendekatan secara persuasip, pelatihan dan praktek ketrampilan, dengan tujuan agar termotivasi untuk berwirausaha.

Untuk lebih jelasnya peneliti sajikan kerangka pemikiran perancangan model pembinaan sebagai berikut :

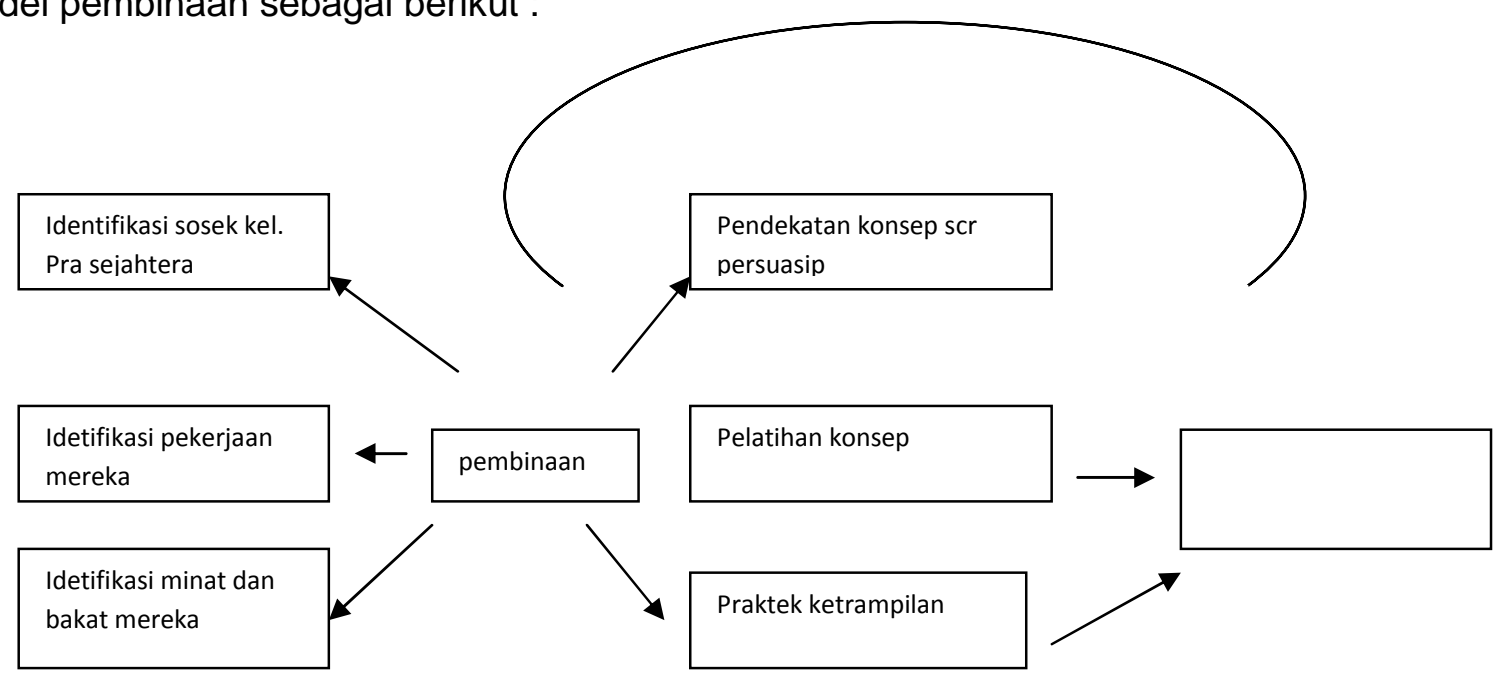

Gambar 1: Kerangka Konseptual Penelitian

\section{ANALISIS DAN PEMBAHASAN}

\section{Hasil Penelitian}

1. Jawaban pertanyaan; berapa lama Bapak/lbu telah menerima program bantuan pemerintah?

Hasil Jawaban dari pertanyaan di atas adalah dari 94 responden 16 orang $(17 \%)$ menerima bantuan dalam 1 tahun dan 78 orang telah menerima bantuan selama lebih dari 2 tahun ( $83 \%$ ). Hal ini menunjukan bahwa sebagian besar responden telah menerima bantuan program pemerintah dalam waktu yang relatif lama namun penerima program 
tersebut dari sisi perekonomiannya juga belum mengalami perubahan yang signifikan.

\section{Jawaban pertanyaan; Pekerjaan yang digeluti saat ini?}

Jawaban responden atas pertanyaan pekerjaan apa yang digeluti saat ini adalah 20 responden ( $21 \%$ ) bekerja pada bidang pertanian, 15 responden (16\%) bekerja sebagai pedagang kecil , 53 responden (56\%) bekerja di tempat orang pada berbagai usaha kecil rumahan, seperti usaha tempe, usaha mebel, usaha kerupuk. pembuatan gula aren.. 2 orang responden ( $2 \%$ ) berprofesi sebagai nelayan tradisional dan 4 responden (4\%) berprofesi sebagai buruh bangunan.

Jawaban diatas memberikan gambaran bahwa sebagian penerima program-program pemerintah masih belum memiliki usaha mandiri dan masih sangat bergantung dengan usaha orang lain dikarenakan mereke bekerja pada usaha orang lain. Hal ini juga dapat bernilai positif dalam pengembangan kewirausahaan, setidaknya responden yang telah bekerja di tempat lain telah memiliki pengalaman dalam berwirausaha hanya saja belum dilakukan sendiri.

3. Jawaban pertanyaan; Bagi yang bekerja di industri rumahan, sudah berapa lama melakukan pekerjaan tersebut?

Responden menjawab dengan variasi waktu yang berbeda, 12 responden (13\%) menjawab bekerja di usaha tersebut sudah 1 tahun, 39 responden (41\%) telah bekerja selama 2 tahun dan 43 responden (46\%) telah bekerja lebih dari 3 tahun. Hasil di atas meggambarkan bahwa selama menerima program bantuan dari pemerintah, mayoritas penerima bantuan masih bekerja dengan orang lain.

\section{Jawaban pertanyaan; apakah berminat untuk berwirausaha sendiri?}

Hasil rekapitulasi jawaban responden atas pertanyaan di atas adalah 66 responden ( $70 \%$ ) menyatakan sangat berminat untuk membuka usaha sendiri, 16 responden (17\%) menyatakan berminat membuka usaha sendiri, 9 responden (10\%) menjawab ragu-ragu, 2 responden (2\%) menjawab tidak berminat dan 1 responden (1\%) menjawab sangat tidak berminat.

Hasil di atas menunjukan bahwa semangat dan minat berwirausaha untuk meuju kemandirian dari responden sangat tinggi, hal ini sangat baik sebagai modal dasar dalam melakukan wirausaha yaitu semangat perubahan hidup yang mereka miliki. Terhadp 3 responden yang menyatakan tidak berminat melakukan wirausaha hal ini dikarenakan adanya trauma kegagalan atas usaha yang pernah dilakukan sebelumnya.

5. Jawaban pertanyaan; Apa masalah utama yang menjadi penghambat dalam memulai usaha?

Hasil jawaban responden adalah sebagai berikut: 75 responden (80 \%) menyatakan bahwa modal (Uang) adalah faktor yang utama menjadi penghambat dalam memulai usaha, 13 responden (14\%) menjawab bahwa tidak ada ide bisnis untuk memulainya dan 6 responden $(6 \%)$ responden menjawab tidak memiliki bahan baku untuk memulai usaha mandiri.

Jawaban di atas sangat menarik, dikarenakan mayoritas responden $(80 \%)$ menyatakan bahwa uang adalah faktor utama dalam memulai berusaha. Hal ini yang perlu mendapat perhatian serius adalam usaha 
merubah paradikma dalam berbisnis dimana masalah utama yang sebenarnya adalah ada tidaknya ide bisnis yang akan dilakukan jika saja mereka sudah memiliki uang, sebagian besar juga masih mengatakan nanti akan dipikirkan kembali setelah ada uang.

Dalam beberapa bisnis yang telah sukses, uang sebenarnya bukan masalah utama yang menghambat ketika, bisnis tersebut dimulai, masalahnya adalah ada pada ada dan tidaknya ide kreatif dalam memulai bisnisnya, sebuah ide bisnis yang prospektif akan dapat ditawarkan untuk di kerjasamakan dengan pihak lain yang memiliki kelebihan finansial meskipun pemilik ide tidak memiliki uang yang cukup.

6. Jawaban atas pertanyaan; bentuk pelatihan yang pernah didapatkan dari pemerintah?

Sebanyak 88 responden (94\%) menyatakan belum pernah mendapat pelatihan apapun dari pemerintah yang berkaitan dengan kewirausahan, 4 responden ( $4 \%$ ) pernah mendapatkan pelatihan dalam bidang pemasaran dan 2 orang responden (2\%) pernah mendapatkan pelatihan administrasi bisnis. Hasil di atas menggambarkan bahwa pemahaman kewirausahaan masih sangat minim dalam benak penerima program pemerintah untuk pengentasan kemiskinan dikarenakan kurangnya pelatihan dalam bidang kewirausahaan.

\section{Jawaban atas pertanyaan; apakah pernah mendapatkan pelatihan} kewirausahaan dari pihak swasta?

Jawaban responden yang didapat adalah bahwa 91 responden (97\%) menjawab tidk pernah, 1 orang responden (1\%) menjawab pernah dalam bidang pemasaran dan 2 orang responden (2\%) pernah mendapat dalam bidang administrasi. Hal di atas menggambarkan bahwa masih kurangnya kepedulian beberapa perusahaan swasta yang beroperasi di wilayah samarinda ilir, terutama perusahaan yang beroperasi di kelurahan pelita.

8. Jawaban atas pertanyaan; apakah pernah mendapatkan pelatihan kewirausahaan dari lembaga pendidikan ( Kampus, Sekolah)?

Jawaban responden dari pertanyaan di atas didapat bahwa 83 Responden (88\%) menyatakan tidak pernah mendapat pelatihan dari lembaga pendidikan yang ada, 10 orang responden (11\%) pernah mendapatkan pelatihan teknik produksi dari salah satu lembaga pendidikan dan 2 responden (1\%) menyatakan pernah mendapatkan pelatihan pemasaran.

9. Jawaban atas pertanyaan; Jika akan diberikan pelatihan, Model Pelatihan yang diharapkan adalah?

Pilihan jawaban atas pertanyaan tersebut adalah berupa ceramah umum, mendatangkan pelatih khusus pada usaha tertentu, pelatihan langsung dilapangan, dan studi banding ke tempat lain. Jawaban yang didapat dari responden adalah 2 orang responden ( $2 \%$ ) mengharapkan pelatihan dengan model ceramah umum, 60 orang responden $(64 \%)$ mengharapkan model pelatihan On The Job Trainning, 5 orang responden (5\%) menginginkan model pelatihan dengan mentoring, 7 responden ( $7 \%$ ) meninginkan pelatihan dengan pendampingan secara berkelanjutan, dan 20 responden $(21 \%)$ mengharapkan model pelatihan studi banding. 
10. Jawaban atas pertanyaan; materi apa yang diharapkan untuk segera dilakukan pelatihan?

Jawaban responden untuk pertanyan di atas adalahsebagai berikut: 67 responden ( $71 \%$ mengharapkan pelatihan segera dengan materi mencari ide berwirausaha, 7 orang responden (7\%) mengharapkan materi pelatihan tentang strategi pemasaran produk, 12 orang responden $(13 \%)$ mengharapkan materi mengenai pengembangan produk 4 orang responden (4\%) mengharapkan materi pelatihan tentang modal usaha dan 4 responden lainya menjawab menginginkan materi pelatihan tentang manajemen resiko dalam berusaha.

Tabel 5.1 Rekpitulasi jawaban responden

\begin{tabular}{|c|c|c|c|c|c|c|c|c|}
\hline \multirow{2}{*}{ NO } & \multirow{2}{*}{ PERTANYAAN } & \multicolumn{6}{|c|}{ FREKUENSI JAWABAN } & \multirow{2}{*}{ RES } \\
\hline & & a & b & c & d & e & f & \\
\hline 1 & $\begin{array}{l}\text { Berapa lama menerima Program bantuan } \\
\text { pemerintah }\end{array}$ & 16 & 78 & & & & & 94 \\
\hline 2 & Pekerjaan yang digeluti aat ini & 20 & 15 & 53 & 2 & 4 & & 94 \\
\hline 3 & $\begin{array}{l}\text { Untuk yang bekerja di Usaha kecil Berapa } \\
\text { lama bekerja pada usaha tersebut }\end{array}$ & 12 & 39 & 43 & & & & 94 \\
\hline 4 & Apakah berminat untuk berwirausaha & 66 & 16 & 9 & 2 & 1 & & 94 \\
\hline 5 & $\begin{array}{l}\text { Masalah utama yang dirasakan menjadi } \\
\text { penghambat memulai usaha }\end{array}$ & 75 & 13 & 6 & & & & 94 \\
\hline 6 & $\begin{array}{l}\text { Pelatihan kewirausahaan yang pernah } \\
\text { didapat dari pemerintah }\end{array}$ & 4 & 2 & & & 88 & & 94 \\
\hline 7 & $\begin{array}{l}\text { Pelatihan kewirausahaan yang pernah didapat } \\
\text { dari lembaga swasta }\end{array}$ & 1 & 2 & & & 91 & & 94 \\
\hline 8 & $\begin{array}{l}\text { Pelatihan kewirausahaan yang pernah } \\
\text { didapat dari lembaga pendidikan (lembaga } \\
\text { kursus, kampus) }\end{array}$ & 1 & & 10 & & 83 & & 94 \\
\hline 9 & $\begin{array}{l}\text { Jika akan diberikan pelatihan, Model Pelatihan } \\
\text { yang diharapkan adalah }\end{array}$ & 2 & 60 & 5 & 7 & 20 & & 94 \\
\hline 10 & $\begin{array}{l}\text { Jika diberikan pelatihan, Program pelatihan } \\
\text { yang sangat diharapkan segera dilakukan }\end{array}$ & 67 & 7 & 12 & 4 & 4 & & 94 \\
\hline
\end{tabular}


Tabel 5.2 Prosentase jawaban responden

\begin{tabular}{|c|c|c|c|c|c|c|c|c|}
\hline \multirow{2}{*}{ NO } & \multirow{2}{*}{ PERTANYAAN } & \multicolumn{6}{|c|}{ PERSENTASE JAWABAN } & \multirow{2}{*}{$\begin{array}{c}\text { TOT } \\
\text { AL }\end{array}$} \\
\hline & & $\mathbf{a}$ & b & C & d & e & $f$ & \\
\hline 1 & $\begin{array}{l}\text { Berapa lama menerima Program bantuan } \\
\text { pemerintah }\end{array}$ & 17 & 83 & & & & & 100 \\
\hline 2 & Pekerjaan yang digeliti saat ini & 21 & 16 & 56 & 2 & 4 & & 100 \\
\hline 3 & $\begin{array}{l}\text { Berapa lama bekerja pada usaha kecil } \\
\text { tersebut }\end{array}$ & 13 & 41 & 46 & & & & 100 \\
\hline 4 & Apakah berminat untuk berwirausaha & 70 & 17 & 10 & 2 & 1 & & 100 \\
\hline 5 & $\begin{array}{l}\text { Masalah utama yang dirasakan menjadi } \\
\text { penghambat memulai usaha }\end{array}$ & 80 & 14 & 6 & & & & 100 \\
\hline 6 & $\begin{array}{l}\text { Pelatihan kewirausahaan yang pernah } \\
\text { didapat dari pemerintah }\end{array}$ & 4 & 2 & & & 94 & & 100 \\
\hline 7 & $\begin{array}{l}\text { Pelatihan kewirausahaan yang pernah didapat } \\
\text { dari lembaga swasta }\end{array}$ & 1 & 2 & & & 97 & & 100 \\
\hline 8 & $\begin{array}{l}\text { Pelatihan kewirausahaan yang pernah } \\
\text { didapat dari lembaga pendidikan (lembaga } \\
\text { kursus, kampus) }\end{array}$ & 1 & & 11 & & 88 & & 100 \\
\hline 9 & $\begin{array}{l}\text { Jika akan diberikan pelatihan, Model } \\
\text { Pelatihan yang diharapkan adalah }\end{array}$ & 2 & 64 & 5 & 7 & 21 & & 100 \\
\hline 10 & $\begin{array}{l}\text { Program pelatihan yang sangat diharapkan } \\
\text { segera dilakukan }\end{array}$ & 71 & 7 & 13 & 4 & 4 & & 100 \\
\hline
\end{tabular}

\section{Pembahasan}

.Fakta menunjukan sebagian besar keluarga miskin pada umumnya berpengetahuan rendah, maka perlu disederhanakan dalam melakukan pembinaan terhadap mereka. Adapun pembinaan yang ditawarkan adalah :

1) Diberi pelatihan tentang jiwa wirausaha

Tahap pertama adalah menanamkan jiwa yang tidak gampang menyerah dengan keadaan saat ini, salah satu jalan yang dapat dilakukan adalah dengan berwira usaha, jangan putus asa hanya karena pendidikan rendah, tidak punya uang, terlalu tua, terlalu muda, tidak berbakat dan alasan-alasan klasik lainya. Jiwa yang bagaimana yang harus dimiliki oleh seorang wirausaha Jiwa yang perlu ditanamkan tentunya adalah mempunyai sikap mandiri, bekerja keras, siap dengan tantangan, mampu memanfaatkan momen dan berjiwa kompetitif.

2) Diberi bimbingan bagaimana membuka usaha mandiri dengan membuat Rencana Perusahaan.

Rencana usaha yang dimaksudkan meliputi sifat perusahaan, pasar sasaran, kelebihan-kelebihan perusahaan terhadap pesaing, sumber dana serta kualifikasi pemiliknya.

3) Pengenalan Pasar:

Dalam menganalisa pasar yang dibicarakan adalah ukuran pasar, sasaran, kebutuhan produk/jasa dan sifat persaingan 
4) Pembiayaan meliputi sumber modal yang bisa diperoleh misalnya dari milik sendiri, pinjam dari keluarga/teman, bantuan dan Bank.modal harus dirinci secara jelas.

5) Pengelolaan karyawan meliputi deskripsi pekerjaan, bagan organisasi, manajer mempunyai keahlian yang diperlukan untuk mengawali dan mengoperasikan perusahaan

6) Pencatatan akuntansi menghasilkan laporan yang menerangkan kondisi keuangan usaha

\section{KESIMPULAN DAN SARAN}

\section{Kesimpulan}

Berdasarkan hasil analisis dalam penelitian ini maka penulis dapat menarik kesimpulan sebagaai berikut:

1. Masih terdapat keluarga miskin yang menerima program bantuan pemerintah dalam upaya pengentasan kemiskinan

2. Program bantuan pemerintah yang diterima saat ini belum dapat mengankat secara nyata tingkat kehidupan keluarga miskin di Kecamatan Samarinda llir dan hanya ddapat membantu mempertahankan daya hidup saja

3. Terdapat minat yang cukup kuat dari penerima program bantuan pemerintah untuk berwirausaha demi kemandirian ekonomi yang diharapkan

4. Diperlukan pelatihan yang lebih intens dari berbagai pihak untuk membuka paradikma berwirausaha, dimana selama ini pemahaman masyarakat untuk bisa menjadi pengusaha harus memiliki modal uang terlebih dahulu.

\section{Saran}

Berdasarkan hasil analisis dalam penelitian ini maka penulis memberikan saran sebagaai berikut:

1. Program bantuan pemerintah (pemberian raskin) hendaknya dievaluasi dan didukung dengan program pelatihan kewirausahaan kepada masyarakat penerima program tersebut.

2. Titik fokus pada pelatihan awal kewirausahaan adalah pada tujuan merubah paradigma bahwa kemiskinan itu bukanlah "takdir" yang tidak bisa dirubah serta pemahaman bahwa uang bukan segalanya dalam berwirausaha.

3. Pemerintah menyusun program pembiaan kewirausahaan secara terpadu bagi keluarga miskin mulai dari penggalian ide usaha, permodalan, produksi dan pemasaran.

\section{DAFTAR PUSTAKA.}

Ali Hasan.(2008) Marketing. Media Pressindo Yogyakarta

Samarinda dalam angka (2011/2012)

Geoffrey G. Meredith et al. (2002). Kewirausahaan : Teori dan praktek. PPM. Jakarta 
Hariwijaya M. (2006). Cara Pintar Lobi \& Negosiasi (Bisnis, Politik dan Pengembangan SDM). Tugu Publisher Yogyakarta.

Husein Umar 1999. Metode Penelitian, PT Raja Grafindo Persada Jakarta.

I Ketut Gede Yudantara (2006). Mengubah Ketidakpastian Menjadi Kekuatan. PT Gramedia. Jakarta

Kasmir (2007). Kewirausahaan. PT Rajagrafindo Persada, Jakarta.

Koentjaraningrat (1993). Metode - Metode Penelitian Masyarakat. PT Gramedia Jakarta

Mary Ellen Guffey, Kathleen rhodes, Patricia Rogin. (2006). Komunikasi Bisnis :

Proses dan Produk, Edisi 4, Salemba empat Jakarta.

Mas'ud Machfoedz (2005). Kewirausahaan. Metode, Manajemen dan Implementasi. BPFE-Yogyakarta.

Philip Kotler. (2005). Manajemen Pemasaran Jilid 2 Edisi kesebelas, PT Indeks Kelompok Gramedia Jakarta

Reinald Khasali, (2002) Change, Gramedia Pustaka,

Z. Heflin Frinces, (2004). Kewirausahaan dan Inovasi Bisnis, Darussalam Yogyakarta. 